\title{
THE FULL COMPENSATION DOCTRINE IN CORPORATE REORGANIZATIONS: A SCHIZOPHRENIC STANDARD
}

DEPRESSION-BORN financial difficulties brought a mass of corporate reorganizations before judicial and administrative tribunals. ${ }^{1}$ The decisions of these bodies elaborated and refined Boyd's ${ }^{2}$ command that senior claimants be paicl before juniors participate in the assets of the rejuvenated company. ${ }^{a}$ This doctrine demands that the new capitalization reflect a reasonable valuation of the emerging company's assets. The new security structure must be "feasible" : fixed charges and debt maturities must be geared to avoid default due to fluctuations of the business cycle. Within the new capital framework at plan must be "fair and equitable."4

These "words of art" require that claims of creditors must be satisfied strictly in the order of their contractual priorities. 5 Under this rule of "absolute priority," applicable to both solvent and insolvent corporations, ${ }^{0}$ senior claimants must be fully compensated for the "entire bundle of rights" they surrender, i.e., the full value of their old claims. Payment may be in either cash or securities, and in the issuance of the latter the relative priorities of the old

1. The Interstate Commerce Commission and the Securities Exchange Commission are the two agencies that have handled the bulk of the reorganization cases, and their views have profoundly affected the rules of reorganization law.

2. Northern Pacific Ry. v. Boyd, 228 U.S. 482 (1913), discussed in Rostow \& Cutler, Competing Systems of Corporate Reorganization: Chapter $X$ and $X I$ of the Bankruptcy Act, 48 Yale L.J. 1334 (1939). For an earlier analysis, placing Boyd in context, sce Frank, Some Realistic Reflections on Some Aspects of Corporate Reorganization, $19 \mathrm{VA}$. L. REv. 541; 19 VA. L. Rev. 698 (1933). For a pre-depression repetition of the Boyd rule, see Kansas City Terminal Ry. v. Central Union Trust Co., 271 U.S. 445, 454 (1926).

3. Case v. Los Angeles Lumber Products Co., 408 U.S. 106 (1939). The decision is discussed in Dodd, The Los Angeles Lumber Products Company Case and Its Implications, 53 Harv. L. Rev. 713 (1940). See also Comment, Distribution of Securitics in Corporate Reorganization, 51 YALE L.J. 85, 109 (1941). The rules of rcorganization were further expanded in Consolidated Rock Products Co. v. Du Bois, 312 U.S. 510 (1941), discussed in Comment, supra; Group of Institutional Investors v. Chicago, Milwaukec, St. Paul \& Pacific R.R., 318 U.S. 523 (1943) ; and Ecker v. Western Pacitic R.R., 318 U.S. 448 (1943). These last two cases are analyzed in Swaine, A Decade of Rcorganization Under Chapter 77 of the Bankruptcy Act, 56 HARv. L. REv. 1037; 56 HAsv. L. REV. 1193 (1943).

4. Consolidated Rock Products Co. v. Du Bois, 312 U.S. 510, 525, 530-1 (1941); Group of Institutional Investors v. Chicago, Milwaukee, St. Paul \& Pacific R.R., 318 U.S. 523, 541, 544-5 (1943). For a discussion of the problem of determining the new capitalization, see Field, Valuation for the Purpose of Corporation Reorganization, 16 ROCKy MT. L. REv. 13 (1943).

A further requirement is that voting control in the reorganized enterprise must be based on substantial equity holdings. Ecker v. Western Pacific R.R., 318 U.S. 448, 481 (1943).

5. Case v. Los Angeles Lumber Products Co., 308 U.S. 106 (1939).

6. See Consolidated Rock Products Co. v. Du Bois, 312 U.S. 510, 527 (1941). 
capital structure need not be maintained. ${ }^{7}$ The requirement is that seniors receive the "equitable," if not the cash, equivalent of the rights which feasibility forces them to surrender. ${ }^{8}$ Only after this is done may junior claimants participate at all ; if the requirement cannot be met, their claims are eliminated as "worthless."

"Fair and equitable" thus requires valuation of the old claim, and a determination that the compensation offered in return is "full." While the first requirement has been the subject of extensive discussion, ${ }^{10}$ the second requires further consideration. The problem arises in four statutory settings: two bankruptcy and two non-bankruptcy. These are: (1) Section 7711 and (2) Chapter $\mathrm{X}^{12}$ of the Bankruptcy Act, (3) Section 11 of the Public Utility Holding Company. Act ${ }^{13}$ and (4) Section 20b of the Interstate Commerce Act. ${ }^{14}$

\section{Full Compensation Under Section 77}

Section 77 of the Bankruptcy Act requires the reorganization of insolvent railroads to be "fair and equitable."15 It necessitates ICC approval of plans before their submission to stockholders. ${ }^{10}$ The poor financial position of debtladen railroads and ICC insistence that "feasibility" requires conservative capital structures wrought drastic changes in railroad capitalizations. "Abso-

7. Id. at 528-30; Ecker v. Western Pacific R.R, 318 U.S. 448 (1943). "But at any rate, under the absolute priority rule of the Boyd case, the stratification of securities issued to creditors need not follow invariably the relative priority of the claimants." Id. at 484. Accord, Group of Institutional Investors v. Chicago, Afilwaukee, St. Paul \& Pacific R.R., 318 U.S. 523, 557-S (1943).

8. Northern Pacific Ry. v. Boyd, $22 S$ U.S. 482, 508 (1913); Kansas City Terminal Ry. v. Central Union Trust Co, 271 U.S. 445, 454, 455 (1923); Consolidated Rod: Products Co. v. Du Bois, 312 U.S. 510, 52S-31 (1941). For an expression of the SECs view of "fair and equitable," see Childs Company, 24 S.E.C. 85, 123 (1946).

9. Case v. Los Angeles Lumber Products Co, 308 U.S. 106, 123 (1939).

10. For an excellent discussion of the various methods in which claims have baen measured and the impact of the "investment value" approach on corporate roarganizations, see Comment, Allocation of Securities in Corporate Reorganizations: Claims AIcasuremcr: Through Investnent Valuc Analysis, 61 Yale L.J. 656 (1952).

11. 47 STAT. 1474 (1933), 11 U.S.C. $\$ 205$ (1940).

12. 52 Stat. $8 \$ 3$ (1938), 11 U.S.C. $\$ 501$ et seq. (1946). This chapter was formerly $\$ 77(B)$ of the Bankruptcy Act, 48 ST.1T. 912 (1934).

13. 49 STAT. $\$ 20$ (1935), 15 U.S.C. \$ 79K (1946).

14. 62 STAT. 163 (1948), 49 U.S.C. $\$ 20 \mathrm{~b}$ (Supp. 1952).

15. 47 Stat. 1474 (1933), 11 U.S.C. $\$ 205$ (1946). For a discussion of the standards of fairness applied in pre-\$ 77 days, see Swaine, Rcorgasization of Corporations: Ccrtains Developments of the Last Decade, 27 CoL. L. Rev. 901 (1927); 28 CoL. L. REy. 29 (1928) ; Rodgers \& Groom, Reorganization of Railroad Corporations Under Scition 77 of the Bankruptcy Act, 33 CoL. L. Rev. 571 (1933). The pre-77 standards and abuses are criticised and the prospects of curing them discussed in Franl; note 2 sufro. For a more recent discussion of railroad reorganizations, see Polatsels, The Wrecls of the Old 77, 34 CORNEIL L.Q. 532 (1949).

16. The procedures and statutory standards of $\$ 77$ are discussed in Dodd, Rcorgor:zation Through Bankruptcy: A Remedy for What?, is HAsv. L. Rev. 1100 (1935). 
lute priority" was enforced, and the total liquidation claim of an old investment became the base line for valuation of its worth, with consideration given to other contract rights.

Ecker v. Western Pacific R.R. ${ }^{17}$ laid the doctrinal cornerstone of full compensation under Section 77. Outstanding, in the order of priority, were (1) RFC-held trustees' certificates; (2) First mortgage bonds; (3) Secured notes held by the RFC, the Railroad Credit Corporation, and the A. C. James Co. The secured indebtedness totalled approximately $\$ 87$ million, while ICCapproved capitalization amounted to $\$ 84$ million, ${ }^{18}$ consisting of first mortgage bonds, income bonds, preferred and common stocks. ${ }^{10}$

Allocation of new securities was based primarily on seniority in the ald capital structure. Thus, at one end of the spectrum, the trustees' certificates received the entire issue of new Firsts. ${ }^{20}$ At the other, unsecured creditors and stockholders were wiped out. ${ }^{21}$ Junior noteholders' claims were partially eliminated since the secured indebtedness exceeded the total value of new securities. ${ }^{22}$ Old first mortgage bondholders received a combination of new Incomes, preferred and common stocks equal to the face amount of their claim. ${ }^{23}$

Allocations between the old Firsts and the notes were complicated by the fact that the notes, though generally junior, held senior liens on some portions of the debtor's road. Both groups received combinations of new Incomes and preferred and common stocks; but the old Firsts obtained a larger percentage of choice securities. ${ }^{24}$ The Supreme Court held the allocations valid despite the ICC's failure to assign dollar values to both the old claims and new securities. Since allocations were based on the properties underlying each mortgage, dollar valuation was "immaterial." 25 Neither did the fact that old Firsts re-

17. 318 U.S. 448 (1943).

18. Id. at 456 . There were also some $\$ 2.75$ million in equipment obligations outstanding, but these were left undisturbed by the reorganization. Id. at 460 .

19. The amount of each type of security to be issued was based on estimates of future earnings. $I d$. at 459,481 .

20. Id. at $485-7$.

21. Id. at 462 .

22. Id. at $480-1$.

23. The combination given in exchange for their $\$ 62.43$ million claim consisted of : (1) $4-1 / 2 \%$ Income Bonds- $\$ 19,716,040$; (2) $5 \%$ Preferred- $\$ 29,574,060$; (3) Common230,593 shares valued at $\$ 57$ per share. Id. at 461 .

This relatively simple method of allocation was complicated by the treatment given the RFC-held notes. These heavily collateralized securities were consolidated with the RFC's trustees' certificates in a single claim, and received compensation on the same basis as the old first mortgages. The effect of the consolidation was simply to improve the treatment of the RFC notes. Unable to see "why all claims of RFC may not be considered by the commission as a single claim," the Court upheld the special treatment. Consideration for it was found in the RFC's acceptance of new Firsts at par in lieu of the more valuable trustee's certificates. Id. at 486-7. Thus, the fact that RFC notes fared better than those of the Railroad Credit Corporation or A. C. James Co. did not violate absolute priority.

24. Ibid.

25. Id. at 482-3. For the opinion of the lower court on this point, see $I n r c$ Western Pacific R.R. Co., 124 F.2d 136, 139 (9th Cir. 1941). 
ceived payment in securities of "lower dignity" invalidate the plan, even though noteholders obtained some similar securities. The notes held a lien senior to the old Firsts on some assets. Mioreover, Boyd does not require stratification of new securities according to the relative priority of old claims."3

Another variation on compensation according to seniority was introduced in the division of losses between notes held by the Railroad Credit Corporation and those of the A. C. James Co. These losses, made necessary because claims exceeded securities to be issued, were prorated according to the security behind the notes, rather than their face amount. Thus the $\mathrm{RCC}$ notes were paid at roughly face value, while equal-ranking but less heavily secured notes of A. C. James bore almost the entire loss. ${ }^{27}$ Since noteholders vere not fully compensated, ${ }^{28}$ exclusion of those junior to them was proper.9 Brushing aside the claim that increased war earnings required higher overall capitalization,,$^{30}$ the Court found the plan fair and equitable.

The requirements of full compensation were developed further in the Chicago, Milwankee, St. Paul \& Pacific case," decided the same day as Western Pacific. Three major bond issues, "Generals," "Fifties," and "Adjustments," secured by liens on major portions of the road, constituted the bulk of the indebtedness. ${ }^{32}$ There were also several smaller issues secured by liens on minor segments of the road. ${ }^{33}$ The plan proposed substitution of

26. Ecker v. Western Pacific R.R., 318 U.S. 448, 484 (1943).

27. The treatment given these classes may be summarized as follows:

$\begin{array}{cccc}\text { Amount of } & \text { New } & \text { New } & \text { New } \\ \text { Old Face } & \text { Incone } & \text { Preferred } & \text { Common } \\ \text { Clain } & \text { Bonds } & \text { Stoct: } & \text { Stocl: } \\ \$ 2.6 \text { million } & \$ 154,111 & \$ 241,6 \$ 1 & \mathbf{3 4 , 4 2 5} \text { shs. } \\ 6.25 \text { million } & 163,724 & 256,756 & \mathbf{3 7 , 6 2 5} \text { shs. }\end{array}$

$\begin{array}{lrrrr}\text { R.C.C. } & \$ 2.6 \text { million } & \$ 154,111 & \$ 241,6 \$ 1 & \mathbf{3 4 , 4 2 5} \text { shs. } \\ \text { A.C. James } & 6.25 \text { million } & 163,724 & 256,756 & \mathbf{3 7 , 6 2 5} \text { shs. }\end{array}$

By way of contrast, RFC-held bonds received $\$ 1,185,200$ in bonds, $\$ 1,777,800$ in preferred and 15,788 shares of common on their claim of roughly $\$ 3.9$ million. Id. at 455 , 461. Had RFC bonds been treated on the same basis as the others, they would have received $\$ 414,175$ in bonds, $\$ 649,516$ in preferred, and "its proportion of common stucli:" Id. at 486 .

28. Id. at $48 s$.

The loss sustained by noteholders is emphasized by the fact that stock: issucd to them was valued at $\$ 62$ per share, while that issued to more senior claimants was valued at $\$ 57$. Id. at 486 .

29. Id. at $476-7,481$.

30. Evidence showed that while the plan was based on future normal earnings of $\$ 2.0$ million, twice that amount had been earned in 1941 and five times it in 1942. Id. at 507. The Court rejected these figures as abnormal, stating that the ICC's forceast was based on past experience in war and peace. Id. at 509.

31. Group of Institutional Investors v. Chicago, Milwaukee, St. Paul \& Pacific R.R., 318 U.S. 523 (1943).

32. The most important was the General MIortgage, with a first lien on the debtors" main line east of the Missouri. Second were the 50-year 5's, vith a first lien on the western line, subject to an \$\$.9 million issue held by the RF.C, and a second lien on the eastern sectors. Third were the Convertible Adjustment bonds, holding the most junior liens on both sectors. Id. at $\mathbf{5 3 0 .}$ 529.

33. Id. at 530-1. The total indebtedness of the road amounted to $\$ 227$ million. Id. at 
system-wide issues as follows: (1) New Firsts, (2) Income bonds in two series: Class A, with a first claim on earnings, and Class B, (3) Non-Cumulative preferred, and (4) Common stock. ${ }^{34}$ Since the new capitalization fell below the claims of bondholders, old stockholders were eliminated. ${ }^{85}$

Distribution of securities was complicated by the fact that various old bonds held first liens on different divisions of the road. Seniority among these lienors was based, therefore, on the relative earnings potential of the securing divisions. Generals, which were secured by the profitable Eastern division, were senior to the other major bond issues. But bonds secured by a first lien on the Milwaukee \& Northern division had an even better earnings record. These bonds, therefore, received a higher percentage of new Firsts than the old Generals; both received the remainder of their claim in new Incomes and preferred stock. ${ }^{36}$

While agreeing with this method, the Supreme Court pointed out that earnings could not be the sole basis for allocation between divisional liens. ${ }^{37}$ Fifties, next senior of the major issues, secured by a first lien on the deficit Western division, were entitled to compensation on the basis of the strategic importance of that division. And issuance to them of securities, equal in rank to some of those given the Generals, was justified. The superior earnings position of the Eastern division was recognized; $60 \%$ of the securities given to the Generals were senior to all of the Fifties' new securities. ${ }^{33}$ Dollar valtation of old and new securities was again deemed unnecessary. ${ }^{30}$

The Generals advanced a further objection to the plan. They received merely the face amount of their claim in securities inferior to those surrendered, while junior interests participated. The Court upheld the objection since Adjustments, wholly junior to both Generals and Fifties, received substantial portions of common stock. ${ }^{40}$ Senior interests were therefore entitled to compensation for their loss of senior rights above the mere receipt of inferior

34. The new First Mortgage was to have a first lien on the entire system, subject to equipment obligations. The Income would have a second system lien. Interest on both classes of Incomes was cumulative to $13 \mathrm{r} / 2 \%$, and both classes had a sinking fund with yearly payments from net income of $1 / 2 \%$ of their aggregate principal. Class B's were convertible into common at a rate of ten shares per bond. The preferred was to have voting rights and could participate in income up to $\$ 1$ per share after common received $\$ 3.50$ per share. Id. at $531-2$, n.5.

35. Id. at 534-5.

36. Ibid. For a discussion of claims valuation in this and other $\S 77$ cascs, sce Comment, 61 YAle L.J. 656, 663-669 (1952).

37. Group of Institutional Investors v. Chicago, Milwaukee, St. Paul \& Pacific R.R., 318 U.S. 523, 561 (1943).

38. Id. at 563. As the Court saw the problem, it was not one of a first and second mortgage, but of fitting each of the divisional liens into the new capital structure so that their relative positions with respect to assets and earnings would be retained. Ibid.

39. "A requirement that dollar values be placed on what each security holder surrenders and on what he receives would create an illusion of certainty where none cxists and would place an impracticable burden on the whole reorganization process." Id. at 565 .

40. Id. at 569. The Adjustment bonds were to receive $\$ 174.9$ million in common stock, which was $\$ 55.5$ million short of their total claim. Id. at 535 . 
securities with a face value equal to the old claim. This "something extra" could be an increased share in earnings, assets or voting control; but without it, senior rights were invaded for the benefit of junior interests.11

The Court found insufficient compensation in participation rights of the new preferred, a sinking fund for the new Firsts, a 3 year cumulative feature of the Incomes, and a voting trust established to protect creditors. Introducing a substantial element of ambiguity into the holding, the Court added that these factors could not be considered as compensation for lost seniority rights because they had not been considered in this light by the ICC. The case was remanded to the Commission with instructions that it determine what additional compensation, qualitative or quantitative, should be given the Generals.

The remittitur of the St. Paul reorganization ${ }^{13}$ brought forth the first response of ICC and District Court to the Supreme Court's formulation of full compensation. The plan was amended to give senior interests "something extra" for loss of seniority. The Generals received $10 \%$ of their claims in cash and an increased portion of new Firsts. Their share of new preferred was reduced accordingly; and the stock thus released was passed to more junior claimants. ${ }^{44}$ Since cash was superior qualitatively to the bonds surrendered, the Generals were found fully compensated.20

The two Denver \& Rio Grande IVestern cases ${ }^{16}$ amplified the Supreme Court's view of contentions, rejected in WVstern Pacific and St. Paul, that

41. Id. at 569-70. Cf. Consolidated Rock Products Co. v. Du Bois, 312 U.S. 510, 529 (1941), discussed pages \$26-7 iifra. This "something extra" requirement has become a vital part of federal reorganization law. Its applications in proceedings under Chapter $\mathrm{X}, \S 11$, and $\S 20 \mathrm{~b}$ are discussed infra.

42. Group of Institutional Investors v. Chicago, Milwaukee, St. Paul \& Pacific RR, 318 U.S. 523, 570-1 (1943). The Court tools the position that it was the ICC's function to determine whether loss of seniority was fully compensated, and that on review its decision must stand if supported by evidence. However, the language uscd in remanding was significant. "Certainly we cannot say that the inclusion in the new sccurities . . . of features normally common to them are adequate compensation for the lost seniority. . . . [T]he Commission and the District Court should determine what the General 3Iurtgage bonds should receive in addition to a face anount of inferior securities equal to the face amount of their old ones, as equitable compensation, qualitative or quantitative, for the loss of their senior rights." Ibid. On the basis of this language, later cases have uniformly accepted the principle that something extra must be given when senior rights are surrendered. See, e.g., Wisconsin Central Ry. Reorganization, 282 I.C.C. 393,497 (1952); Community Gas \& Power Co., 25 S.E.C. 92, 10 (1947).

43. In re Chicago, Milwaukee, St. Paul \& Facific R.R., 5 S F. Supp. 384 (N.D. Ill.,), appeal dismissed, 145 F.2d 299 (7th Cir. 1944), cert. dcuicd sub nom. Parl: v. Group of Institutional Investors, 324 U.S. 857 (1945).

44. In re Chicago, Milwaukee, St. Paul \& Pacific RR, 5S F. Supp. 384, 383 (N.D. I11. 1944). The revised plan also provided a sinking fund for the benefit of old serior creditors, to be created by payments equal to $50 \%$ of dividends paid on new cummon stock. The fund was to be applied first to the retirement of new Firsts, then to Income Bonds, and then to preferred stock. Ibid. New preferred stocltholders were given the right to vote in case their dividends were not paid. Id. at 389.

45. Id. at 391.

46. R.F.C. v. Denver \& Rio Grande Western RR, 328 U.S. 495 (1946), 60 Hurv. 
post-approval changes of circumstance required ICC reexamination of the plan. The Rio Grande reorganization satisfied the claims of seven classes of bondholders, but the eighth (Generals) received only $10 \%$ of their claim.47 The Generals rejected the plan; however, the District Court, utilizing the "cram down" provision of Section 77, approved it on the ground that the Generals' rejection was unreasonable. ${ }^{48}$

After ICC approval, the road prospered due to profitable wartime operations. Claims were reduced by $\$ 8.5$ million and an additional $\$ 30$ million were added to the capital account. ${ }^{49}$ The Generals contended that, since the Commission found all senior creditors fully compensated, both cash accumulations and securities originally allocated to the retired claims belonged to Generals. The Circuit Court agreed. ${ }^{50}$

The Supreme Court reversed. The Circuit Court had fallen into error by assuming that, because Generals participated, creditors senior to them had been paid in full.51 The ICC had made no finding that the cash value of the new securities equalled the face value of the old. Rather it found that the plan as a whole fully compensated senior interests because of the possibility of "unlimited dividends" on common stocks they received."52 Thus the Commission's plan contemplated high wartime earnings-"the one thing that gave senior creditors compensation for the admission of junior claimants ... before the seniors obtained full cash payment. . ." Creditors receiving common stock therefore obtained an equity in all cash accumulated after the plan's effective date. Similarly, once that cut-off date was past, reduction in the size of new bond issues was for the benefit of the new common, compensating them "for their loss of payment in full in cash." 54 Since the plan was fair and equitable, its rejection by the Generals was unreasonable and the District Court's use of the "cram down" provision correct. ${ }^{65}$

L. Rev. 291, 14 U. of CHI L. Rev. 84; Insurance Group Committee v. Denver \& Rio Grande Western R.R., 329 U.S. 607 (1947).

47. R.F.C. v. Denver \& Rio Grande Western R.R., 328 U.S. 495, 502 (1946).

48. In re Denver \& Rio Grande Western R.R., 62 F. Supp. 384 (D. Colo. 1944), rev'd, 150 F.2d 28 (10th Cir. 1945), rev'd stb nom. R.F.C. v. Denver \& Rio Grande Western R.R., 328 U.S. 495 (1946).

49. R.F.C. v. Denver \& Rio Grande Western R.R., 328 U.S. 495, 514, 524 (1946).

50. In re Denver \& Rio Grande Western R.R., 150 F.2d 28, 35-39 (10th Cir. 1945).

51. R.F.C. v. Denver \& Rio Grande Western R.R. 328 U.S. 495, 523 (1946).

52. Id. at 517 .

53. Id. at 518. The Court then pointed out that income for the year just prior to the ICC's approval of the plan was "at its highest." Ibid.

54. Id. at 525. The Court's references to the necessity of giving seniors full cash payment for securities surrendered is emphasized by its citation of the fact that the $\$ 100$ par common was selling on the market for $\$ 31 \frac{1}{2}$. Id. at 519 .

55. Id. at 533-4. Mr. Justice Frankfurter, dissenting, vigorously challenged this view. Since $80 \%$ of a class rejected the plan and a circuit court of appeals agreed with them, he found it difficult to believe that their action was unreasonable or motivated by hostility to the general interest. $I d$. at 537,546 . He concluded that seniors were in effect receiving double payment on their claim: (1) securities for the claim; (2) cash to buy up the claims. Id. at 544-5. 
After unsuccessful attempts to get the District Court to reconsider, junior interests again appealed. This time they argued that post-war changes in circumstances required reexamination of the plan. ${ }^{53}$ The Supreme Court again rejected the request. The allegations of change in circumstance were held fatally defective because they failed to contend that the cash value of allotted securities equalled the face amount of senior claims. ${ }^{57}$ The Court then emphasized its cash value approach by citing the current market prices of the new securities. ${ }^{\text {ss }}$

The latest decision in another case, the Wrisconsin Central reorganization, indicates that the advent of Rio Grande did not alter the ICC's original view, exemplified in the St. Paul remittitur, ${ }^{\text {co }}$ that future cash accumulations should benefit all claimants holding any equity. The Irisconsin Central plan provided for distribution of such cash to the most senior creditors and release of an equivalent face amount of allocated securities to junior interests. ${ }^{01}$

Equally important was the ICC's compliance with the "something extra" requirement. The Commission specifically rejected the contention that full compensation is achieved only when the market value of new securities equals old claims. ${ }^{62}$ Old Firsts received 90\% of their claim in new Firsts and 10\% in cash. ${ }^{63}$ The ICC's treatment of more junior Superior and Duluth divisional

56. Insurance Group Committee v. Denver \& Rio Grande Western R.R, 329 U.S. 607 (1947).

57. Id. at 617.

58. The table drawn by the Court showed that for the year prcceding, the Marlset High-Low range of all the new securitics, except the First bonds, was well below par. Id. at 617 n.6. The implication of this table and the language used is that seniors are not fully compensated until they receive new sccurities which sell on the marlset for prices equal to the face value of old claims.

For another cash value approach to the Rio Grande rcorganization, see Guaranty Trust Co. v. Chase National Bank, 194 Misc. 62S, \&6 N.Y.S.2d 505 (Sup. Ct. 1949), aff'd, 277 App. Div. 767 (1st Dep't 1950), aff'd, 302 N.Y. 658, 98 N.E.2d 474, ccrt. denicd sub nom. Baird v. Guaranty Trust Co., 342 U.S. $\$ 19$ (1951). The court there held that regardless of whether seniors were found fully compensated under $\$ 77$, they may collect on accommodation collateral unless their bankruptcy payments cqualled 100 cents on the dollar.

59. Wisconsin Central Ry. Reorganization, 282 I.C.C. 393 (1952). The rasd entered equity receivership in 1932 and filed a bankruptcy petition under $\S 77$ in 1944. Id. at 395 . Earlier ICC proceedings are reported at 267 I.C.C. 423 (1947).

60. There the ICC did precisely what the Supreme Court later refused to require of it. The $\$ 15$ million cash distribution came from post-approval earnings, and the $\$ 7$ million of new Firsts came from retirement of a senior claim. Moreover, by passing released stocks down the line, the revision allowed juniors to obtain greater participation. See pages 817-18 stipra.

61. Wisconsin Central Ry. Reorganization, 282 I.C.C. 393, 498 (1952). A further contrast with Rio Graide is shown by the fact that, largely on the basis of increased earnings and physical improvement of the road, the ICC increased the capitalization from the maximum of $\$ 46.8$ million allowed in the previous plan, id. at 399 , to $\$ 59$ million. Id. at 431 .

62. Wisconsin Central Ry. Reorganization, 282 I.C.C. $567,570-2$ (1952).

63. Wisconsin Central Ry. Reorganization, 2S2 I.C.C. 393, 479 (1952). While their maturity was extended, the old Firsts received a lien on all the debtors" property, and also 
bonds further clarified its view of full compensation. ${ }^{64}$ Starting from the proposition that these bonds had a $\$ 10$ million claim bearing $4 \%$ interest, the ICC stated that qualitatively full compensation required an annual return of $\$ 400,000$ per year. New bonds previously allotted to them would bring in $\$ 230,000$, and therefore common stock sufficient to earn an average of $\$ 170,000$ must also be allocated.65 The total face value of the bonds and stock necessary to produce the required earnings was $\$ 11.25$ million. The excess of $\$ 1.25$ million quantitatively compensated Superior and Duluths for lost seniority. Thus issue of a bonus amount of new securities was introduced as an alternative to qualitative superiority as a means of providing "something extra."

Recent chapters in the quarter-century Missouri Pacific reorganization ou shed further light on many aspects of Section 77 reorganizations. In sharp contrast to Rio Grande, the Eighth Circuit in 1947 ordered the ICC to reconsider its plan because of changed circumstances. ${ }^{67}$ The ICC agreed that a substantial reduction in outstanding claims and large cash accumulations stemming from greatly increased profits made revision necessary. ${ }^{08}$ The result was greater participation of junior interests. ${ }^{69}$

obtained a sinking fund. They were found fully compensated, even though juniors also received new Firsts. Id. at 496 . For a complete summary of the proposed capital structure in tabular form, see id. App. A at 509.

64. The Superior and Duluth divisional Firsts were competing for seniority with General Refundings who held a second lien on the entire system. Analysis of the underlying assets of each issue disclosed that the Refundings' secured position was stronger. Moreover, one third of the Superior and Duluth's claim exceeded the security and was therefore eliminated. Id. at 488-90. Both classes received securities in excess of the face value of their claims, but Refundings received a better mix. The Superior and Duluths received new securities with a total face amount of $\$ 1,500$, including $\$ 550$ in new Incomes, for each $\$ 1,333.3$ of claim. Refundings received $\$ 1,650$, including $\$ 1,000$ in new Incomes, per $\$ 1,593.6$ of claim. Each received $\$ 150$ in new Firsts. Id. App. A at 510 .

65. Id. at 497 n.64.

66. Missouri Pacific R.R. Reorganization, 275 I.C.C. 59, 275 I.C.C. 203 (1949). See also State of Texas v. Group of Institutional Investors, 93 F. Supp. 832 (E.D. Mo. 1950), aff'd, 191 F.2d 265 (8th Cir. 1951), cert. denied, 342 U.S. 904 (1952). The debtor first filed under $\S 77$ in 1933, Missouri Pacific R.R. Reorganization, 212 I.C.C. 662 (1936), and has been before the Commission periodically ever since. E.g., 230 I.C.C. 5 (1938); 257 I.C.C. 479 (1944). Another I.C.C. decision in the case is pending.

67. Wright v. Group of Institutional Investors, 163 F.2d 1022 (8th Cir. 1947). See Missouri Pacific R.R. Reorganization, 275 I.C.C. 59, 60 (1949).

68. Claims against the company had been reduced by about $\$ 45.5$ million, while cash on hand at the close of 1948 amounted to $\$ 82.6$ million. Id. at $60-61$. Of this amount, $\$ 35.5$ million was available for distribution to senior creditors. Id. at 122 . The prior plan had been based on estimated normal earnings of $\$ 22$ million, but the 1943-48 average had been $\$ 39$ million. Id. at $84-5$.

69. Under the 1944 plan, junior bondholders received warrants, and preferred stockholders nothing. Missouri Pacific R.R., 257 I.C.C. 479, App. E at 577-579 (1944). Under the 1949 plan, however, these bondholders received new preferred and common stock, while old preferred holders received nearly $20 \%$ of their claim in new common. Missouri Pacific R.R., 275 I.C.C. 59, 128-130 (1949). These changes resulted from an increase in capitalizable income from $\$ 22$ million to $\$ 25.4$ million. Id. at 101-2. 
The compensation of bondholders produced some variations on the $S t$. Paul remittitur and IVisconsin Contral. The senior First \& Refundings received the face amount of their claim, including an $11.7 \%$ cash distribution, as the qualitative "extra." The more junior Generals obtained preferred, while junior-most Convertibles received a combination of preferred and common stock. Their reductions in seniority were compensated by increased income expectations. ${ }^{\mathbf{7 1}}$ Special treatment was accorded Serial bonds secured by $82 \%$ of the profitable New Orleans Division's common stock. Because of its earnings and bright prospects New Orleans' stock was valued at $150 \%$ of par. In recognition of the high value of this collateral, Serial bonds received series A Generals, the most junior class issued to the First \& Refundings. The remainder of their secured claim was met by series B Generals. But this allocation failed to compensate them for their loss of prospective New Orleans earnings and $82 \%$ voting control of that road. They therefore received share of new common per bond, and preferred stock for the unsecured portion of their claim. ${ }^{72}$ The Eighth Circuit approved the plan. ${ }^{73}$

Because the Missouri Pacific's earning power had been underestimated, the ICC reopened the proceedings in $1952 .{ }^{74}$ The 1954 examiners' report increased capitalization by one-third and allowed junior interests greater participation. ${ }^{2 \pi}$ Absolute priority, said the examiners, required that old preferred receive full compensation for both their principal and accrued interest. ${ }^{70}$ Observance of liquidation claims is mandatory since bankruptcy substitutes for liquidation. Before old common could participate, old preferred was entitled to new class A common, equal in face amount to its claim. ${ }^{77}$

70. Id. at 122. See id. Apps. C and D, at 162-4.

71. The 5\% rate the Generals would receive on their new preferrcd was higher than their old $4 \%$ coupon rate, and under the plan the $5 \%$ would be covered 1.5 times by earnings, while in the past the $4 \%$ rate was covered 1.1 times. Similarly the Refundings, though sursendering a $5 \% / 2 \%$ coupon rate, were thought to be better of beause they would in fact receive more in the future than the $1 / 10$ of their counon rate which was the past average. Id. at $128-9$.

72. Id. at 125-6. In the anticipated normal year this combination of securities received by the 5\%/4's would yield a return of $\$ 50.38$ per 1000 of old claim. Had the New Orleans been allowed to form a separate company this figure would have reached $\$ 59.18$, but this loss of prospective earnings was made up for because of the increased quality of the new securities. Id. at 127.

73. State of Texas v. Group of Institutional Investors, 191 F.2d 265 (Sth Cir. 1951).

74. Missouri Pacific R.R. Reorganization, 282 I.C.C. 629 (1952). The ICC withdrew the plan under 62 STAT. 167 (194S), 11 U.S.C. \$208(3) (Supp. 1952), on the ground that economic testimony indicated changed circumstances requiring reevaluation of the entire proposal.

75. Missouri Pacific RR Reorganization, ICC Finance Dlst 9918, Feb. 17, 1954. The overall capitalization was increased from $\$ 611$ million to $\$ 310$ million. Id. at 70 .

76. The thesis that accrued interest and principal should be treated identially has a sound basis in economic theory. See Fischer, The Nature or Capiral and Incusese 215-16 (1905). It also accords with the legal requirements laid down for banlsrugitey reorganizations in Consolidated Rock Products v. Du Bois, 312 U.S. 510 (1941). See page 827 infra.

77. Mlissouri Pacific R.R. Reorganization ICC Finance Dlit. 9918, Feb. 17, 1954, p. 90 . 
Although compensation of preferred absorbed the entire approved capitalization, the possibility that earnings might again exceed expectations required recognition of old common's potential value. Warrants were therefore issued. To protect old preferred, these warrants were made redeemable in class $B$ common. Moreover, their exercise was conditioned on maintenance of high earnings for seven consecutive years. ${ }^{78}$ This scheme was deemed justified because conversion of the warrants would not increase the value of new securities beyond the system's capitalizable assets. ${ }^{70}$ Why this finding did not require capitalization sufficient to allow immediate participation by old common was not made clear.

The distributions to preferred and common appear to violate the canons of full compensation. Old preferred received the face amount of its claim in inferior securities while common participated. ${ }^{80}$ Preferred's relative seniority was maintained by the division of new common into two classes. But its old cumulative rights were surrendered without additional compensation. This apparent violation of the St. Paul decision was also left unexplained by the examiners. ${ }^{81}$

Even more dubious was the report's departure from prior ICC practice in fixing interest rates on senior securities. Senior bondholders' insistence that present market conditions required increased interest rates ${ }^{82}$ forced the examiners to determine the applicable yardstick. Rejecting theoretical economics, the report argued that full compensation requires new securities to sell at or near par if issued in the face amount of old claims. ${ }^{83}$ Hence, they held, al-

78. Id. at 90-91. The seven years must fall within the next fifteen. The plan provided a sliding scale of participation by common based on earnings in the stipulated period. The scale was as follows:

$\begin{array}{ccc}\text { Systcm Earnings } & \text { Earnings per } & \text { Shares of Class } B \\ \text { Before Taxes } & \text { Class } A \text { Sh. } & \text { per Warrant } \\ \$ 76.1 \text { million } & \$ 11.00 & 0.2 \\ \$ 82.5 \text { million } & \$ 12.50 & 0.6 \\ \$ 89.1 \text { million } & \$ 14.30 & 1.0\end{array}$

If issued, Class $B$ common was entitled to dividend parity with Class $A$ only after the latter had received $\$ 5$ per share in the dividend year.

79. Id. at 92 .

80. While common's exercise of the warrants may be problematical, their issuance constitutes "participation" in a reorganization context. See Niagara Hudson Power Corp. v. Leventritt, 340 U.S. 336 (1951).

81. The treatment of Convertible $5 \frac{1}{2} \%$ bonds may be open to the same criticism. These bonds received $4 / 5$ of their claim in $5 \%$ preferred and $1 \%$ in $43 / 4 \%$ contingent interest bonds. Missouri Pacific R.R. Reorganization, ICC Finance Dkt. 9918, Feb. 17, 1954, Apps. "I" and "J". While the examiners made no attempt to justify this result, it is conceivable that new $43 / 4$ 's were qualitatively superior to the old Convertibles, thus satisfying the St. Paul doctrine despite the inferior status of the new preferred.

82. See, e.g., Brief for First and Refunding Bondholders, pp. 17-21, Brief for Secured Serial 5y/4's, pp. 21-2, Missouri Pacific R.R. Reorganization, ICC Finance Dkt. 9918, Feb. 17, 1954.

83. Missouri Pacific R.R. Reorganization, ICC Finance Dkt. 9918, Feb. 17, 1954, p. 55. 
though IVisconsin Central rejected market values as the standard, ". . . the Commission may not ignore the market conditions which may be expected to exist within a reasonable period after the issue of the securities." But But they insisted that present security yields were not controlling because they fluctuate too rapidly. Then, echoing Rio Grandc, they stated the test: whether new securities will have a reasonable chance of sclling at a price equal to old claims. Applying this test to conditions in the security marliet, the report recommended a $1 / 4 \%$ increase in coupon rates. ${ }^{85}$

From an economic viewpoint the result is unsound. It takes little account of the mechanisms that determine long run interest rates. Moreover, it does not coordinate bond interest rates with the return on the railroad's entire capital structure. This return is the keystone of reorganization. MIultiplying its reciprocal (the capitalization rate) by future earnings determines the capitalized value of the railroad. ${ }^{86}$

The capitalization rate is fixed by the price that must be paid for new capital. Assuming profits sufficient to justify future investments, ${ }^{\mathrm{St}}$ this price is set in the capital market. There, lenders confront borrowers and definite supply and demand curves are established. Profits on invested capital must, therefore, be sufficient to divert new capital from competing uses. ${ }^{\text {ss }}$ If they exceed this

S4. Id. at 63 .

85. Id. at 647 .

86. The interest rate (return on capital) is the price of eapital in terms of income and its reciprocal is the rate of capitalization. FisceER, op. cit. sufro note 76 , at 194. Thus, the rate of interest makes it possible to determine the capitalized value of any amount of income. Id. at 202. For example, a business earns $\$ 1,000,000$ per year and pays interest at the rate of $5 \%$. The reciprocal of $5 \%$ is 20 . Thereiore, by multiplying 20 times $\$ 1,000,000$, the capitalized value of $\$ 20,000,000$ is fuund.

87. While the Missouri Pacific's earnings in recent years support this assumption, see Missouri Pacific R.R. Reorganization, ICC Finance Dlt. 9918, Feb. 17, 1954, p. 36, it is not invariably correct. Funds may be obtained to some extent by creation of depreciation and other reserves rather than in the capital market. Thus, a company unable to obtain capital economically may avoid the market price for capital by ploughing bacl: earnings. Fowler, The Depreciation of Capital 109-10 (1934).

88. The surplus value of goods produced over the cost of production is causcd in part by the employment of capital, and the resulting loss of present enjoyment of that engital by those who furnish it. These owners of capital must be compensatcd for this loss. Marsenali, Princtples of Ecovoxics 587 (8th cd. 1930). In short, interest arises from

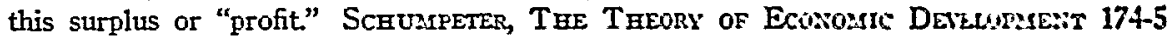
(1949). Capital must be obtained because entrepreneurs must pay for the productive goods they use, and the capital needed to pay for these goods must in turn be paid for, id. at 177 , because present purchasing power is at a premium over future purchasing power. This premium differential is interest. Id. at 188.

Thus, capital is a factor of production which must be paid for and, like any other factor of production, must have a market. This market is the money marliet. Here entrepreneurs, on the demand side, confront holders of capital, on the supply side, and all kinds of economic projects enter the market and compete for realization through the purchase of capital. Id. at 123-6. The supplier is faced with various alternative uses fur his capital and sells it to the highest bidder. FISCHER, op. cit. supra note 76 , at 221 . In this context, the interest rate will tend to balance supply and demand curves. SCHUNIPETER, op. cit. supra, at 191-j. 
amount, excess capital will flow in, driving the profit rate down. Thus, the profit rate on invested capital tends to equal the interest rate on new capital. ${ }^{80}$ The gross interest rate has, however, two components : (1) reward for waiting; (2) reward for risk..0 At a given time the first is generally uniform, while the second varies according to the risk involved. ${ }^{91}$ Therefore, if risks are equal, interest rates on similar investments will be similar.

Today, Class I railroads bear approximately the same risks; therefore their composite interest rate approximates the proper one for the Missouri-Pacific. This rate is reflected in the relation of their profits to book capital, since this is the rate at which necessary capital will be attracted. ${ }^{92}$ If profits were higher, more capital would flow in, raising book values and reducing profit rates. Conversely, if profits were lower, disinvestment would raise the profit rate. Thus, the $4+\%$ which railroads have earned on book capital since $1940^{\circ 3}$ should be the average return, or capitalization rate, for reorganizations. Since senior bonds bear below average risks, their return should be below average. The mere reward for waiting is approximated by the interest on long term government bonds. But senior bonds bear some risk; hence their interest rate should fall in the zone between the rate on government bonds 0.4 and Class I railroads' average return. The $4 \%$ fixed by the ICC in previous reorganizations does precisely this. ${ }^{.5}$ But the $41 / 4 \%$ fixed by the MissouriPacific examiners' report grants senior bonds a return slightly above that zone.

If, as the examiners suggest, security prices have fundamentally declined, past profits of Class I railroads might be irrelevant. But the suggestion appears fallacious. Federal Reserve action, ${ }^{97}$ designed to counteract a hardening of money rates in 1953, evoked a prompt response. Government $31 / 4$ 's rose from $98 \mathrm{~T} / 2$, in May 1953, to 109 in March, while in February, average

89. This equality between the profit and interest rates occurs because new and old capital must earn the same retum for the same risks. MarShald, op. cit. supra note 88 , at 593 .

90. Hicks, Value and Capital 142-3 (1939); Marshall, op. cit. supra note 88, at 588 .

91. Id. at 591.

92. While book capital may not be a perfect index, it appears to be the best available recordation of the capital actually invested in an enterprise.

93. Transcript of Record, p. 8940, Missouri Pacific R.R. Reorganization, ICC Finance Dkt. 9918, Feb. 17, 1954. This 15 year period excludes the abnormally low earnings of the depression.

94. The government long term rate is indicated by the fact that $3 \% / 4 \%$ bonds are selling at about 109. N. Y. Times, April 28, 1954, p. 46, col. 4.

95. See, e.g., Wisconsin Central Ry. Reorganization, 282 I.C.C. 393 (1952); Missouri Pacific R.R. Reorganization, 275 I.C.C. 59 (1949); Group of Institutional Investors v. Chicago, Milwaukee, St. Paul \& Pacific R.R., 318 U.S. 523 (1943).

96. Missouri Pacific R.R. Reorganization, ICC Finance Dkt. 9918, Feb. 17, 1954, p. 66.

97. In the latter half of 1953 the Federal Reserve System renewed open market purchases of government bonds and also eased reserve requirements. By the end of the year these steps freed $\$ 3.8$ billion to meet demands for capital. National City Bank Monthly Letter on Business and Economic Conditions. January, 1954, pp. 6-7. 
bond prices reached a 3-year high. ${ }^{98}$ These fluctuations not only refute the examiners' suggestion, but also indicate the futility of fixing interest rates by current market prices. Between formulation and approval of a plan, market fluctuations are bound to occur. If full compensation requires that senior issues sell at or near par, reorganizations are doomed to endless reopening. While, since 1938 , railroad bond yields varied between $2.78 \%$ and $5.75 \%$, profits on book capital remained steady. Thus, for practical as well as theoretical reasons, returns on book capital furnish a better yardstick than current market price for fixing interest rates.

The Section 77 cases demonstrate the meaning of full compensation in this context. Dollar valuation of new securities need not be balanced against a similar measure of old claims. Neither must the stratification of the old eapital structure be maintained. Rejection of these requirements gives both commission and court considerable freedom in measuring the fullness of compensation and in shaping feasible capital structures.

Read in its proper setting, Rio Grande does not restrict this freedom. It does not require the cash value of new securities to equal the face value of the old. Boyd, in demanding absolute priority, expressly states that creditors need not be paid in cash. ${ }^{100}$ Moreover, the rejection of dollar valuation in Western Pacific and St. Paul bars the contention that new securities must be the cash equivalent of old claims. But Rio Grande does limit review of Section 77 reorganizations at the behest of junior interests. Under its rule, the ICC is not required to reopen proceedings absent a showing that the cash value of new securities exceeds the old claims' face value. This apparently is the view taken by the ICC and lower federal courts, as illustrated by MIissouri-Pacific's reopening and Wisconsin Central's disposition of debt reductions and afteracquired cash. In both cases juniors benefited without any showing that seniors received the cash value of their claims. In view of these precedents, the full Commission may reject the examiners" questionable reliance on marleet prices in the most recent Missouri-Pacific case. Any other result would conflict with the earlier decisions.

Thus, the rules of full compensation are those laid down in Western Pacific

98. Ibid. See note 94 supra. The average market value of 992 bond issues listed on the New York Stock Exchange was \$100.2S and, in aggregate, exceeded their par value by $\$ 00,000$. One month earlier their average market value was $\$ 99.32$. N. Y. Times, Mlarch 25, 1954, p. 47, col. 3.

99. Missouri Pacific R.R. Reorganization, ICC Finance Dlst. 9918, Feb. 17, 1954, p. 64 .

100. Northern Pacific Ry. v. Boyd, 228 U.S. 482 (1913). The court stated that it would not "require the impossible and make it necessary to pay an unsecured creditor in cash as a condition of stockholders retaining an interest in the reorganized company. His interest can be preserved by the issuance, on equitable terms, of income bonds or preferred stock" Id. at 508. This view was reaffirmed in Kansas City Terminal Ry. v. Central Union Trust Co., 271 U.S. 445, 454, 455 (1926). See Franl;, susra note 2, at 558-60. 
and St. Panl. Seniors must receive the face value of their claims to the extent secured, and something extra for surrender of senior rights, if wholly junior claimants are to participate. Subsequent cases have met the test: (1) qualitatively, through partial payment in cash, establishment of sinking funcls, and increased income expectations; or (2) quantitatively, through receipt of new securities with face values exceeding those of old claims.

\section{ChAPTER X}

The reorganization of insolvent, non-railroad corporations is governed by Chapter X, formerly $\S 77 \mathrm{~B}$, of the Bankruptcy Act.101 "Fair and equitable," the statutory prerequisite of approval, is left undefined. But here also, in Case v. Los Angeles Lumber Products Co., ${ }^{102}$ the Supreme Court found in these words the statutory incarnation of "absolute priority." There, the debtor had outstanding one class of bonds and two classes (A and B) of common stock. Total corporate assets amounted to $\$ 830,000$, while bondholders' claims aggregated $\$ 3.8$ million. The Supreme Court rejected the plan, which gave bondholders new preferred stock in the amount of $\$ 641,000$ while allowing Class A common to receive $\$ 188,000$ in new common. ${ }^{103}$ Under the rule of absolute priority, compensation of senior creditors must equal the face amount of their claims. This standard is not met merely by maintaining the old order of seniorities. ${ }^{104}$ Junior interests could participate here only by making a fresh contribution in money or money's worth. ${ }^{105}$ Moreover, while practical adjustments may be made, a plan may not compensate junior interests for surrender of whatever nuisance or "blackmail" value they may have.100

Consolidated Rock Products Co. v. Du Bois ${ }^{107}$ involved Consolidated and its two wholly owned subsidiaries, Union and Consumers. Each subsidiary had an issue of $6 \%$ bonds outstanding, while the parent had issued preferred and common stock. ${ }^{108}$ The plan compensated half the principal of both

101. 52 STAT. 883 (1938), 11 U.S.C. $§ 501$ (1946); §77B: 48 STAT. 912 (1934). The statute requires the court to secure an advisory opinion from the SEC if the bankrupt's indebtedness exceeds $\$ 3$ million. 52 STAT. 890 (1938), 11 U.S.C. $\$ \S 572-5$ (1946). For a discussion of the relation of Chapters X and XI of the Bankruptcy Act, sce Rostow \& Cutler, Competing Systems of Reorganization: Chapters $X$ and $X I$ of the Bankruptey Act, 48 YaLE L.J. 1334 (1939).

102. 308 U.S. 106,115 (1939).

103. Id. at 109-111. The equity of the Class B common was wiped out.

104. Id. at $119-20$.

105. The Court rejected three claims of contribution by the common stock: (1) Continuity of management and the financial standing of the officers benefits the company; (2) The creditors would fare worse if common had elected out-and-out liquidation;

(3) Had the corporation not gone into bankruptcy, creditors could not get any of their principal until maturity, six years distant. The Court felt that recognition of such "contributions" would subvert the rule of absolute priority. Id. at 122 .

106. Id. at 122, 127.

107. 312 U.S. 510 (1941).

108. Union, with greater assets, id. at 517 , had $\$ 2,280,555$ in bonds outstanding, while Consumers' publicly-held indebtedness equalled $\$ 1,358,715$. 285,947 shares of pre- 
bond issues with new twenty-year 5\% contingent bonds. The other half was met with new $5 \%$ non-cumulative preferred stock. Interest on the old bonds, comprising $20 \%$ of bondholders' claims, was eliminated. Old preferred would receive new common on a share-for-share basis, while old common received warrants. Net income of the new company was to be divided, one half to service new issues replacing Consumers' bonds, the other for those replacing Union's. ${ }^{109}$

The Court found the plan inequitable. The equal division of income between the classes of bondholders was unsupported by a proper valuation of the assets securing each class. In the absence of such data, said the court, fairness of the plan "as between Union and Consumers' bondholders cannot be intelligently resolved."110 The failure to determine earning capacity, on which valuations could be based, made the plan unfair in another respect. It must appear that future earnings will cover the interest and dividend requirements of securities issued to seniors. Otherwise they would not be fully compensated and "indefensible participation" of junior interests might result.111

In addition, the plan itself was fatally defective. The failure to treat accrued bond interest on the same basis as principal violated the canons of full compensation. And the plan's treatment of the principal claim failed to satisfy "absolute priority." Bondholders were required to relinquish a $6 \%$ fixed interest claim in exchange for an equal face amount of bonds bearing a contingent $5 \%$ return-securities inferior to those surrendered. ${ }^{112}$ Recognizing that feasibility may require destruction of old priorities, the court ruled that in such cases plans "must accord to the creditor his superior rights in some other way" before junior interests can participate. The Court conceded that the method would vary from case to case, but indicated that increased participation in assets, earnings or control were important criteria. ${ }^{113}$

ferred (liquidation claim $\$ 25$ per share) and 397,455 shares of common were outstanding. Id. at 515.

109. Interest on the bonds was to be cumulative, and both bonds and preierred were to have the benefit of sinking funds. Prior to bond retirement, preferred dividends would be cumulative to the extent earned, and thereafter, fully cumulative. In addition, preferred shareholders were entitled to elect four out of nine directors, except that in the event of delinquency on the new bonds, bondholders would elect six directors.

Warrants issued to common on a one for five old shares basis entitled the holder to purchase one share of new common for one dollar. Preferred also received warrants with exercise prices of two to six dollars, depending on when they were used. Id. at $515-6$.

110. Id. at 524-5. The District Court had found that the fair value of the assets was not enough to cover the respective bond issues, $i d$. at 518 , but this finding was insuficient. Id. at 525 .

111. "The criterion of earning capacity is the essential one ... if the allocation of securities among the various claimants is to be fair and equitable" Id. at 520.

112. Id. at 527-8.

113. Id. at 528-9. Cf. Kansas City Ry. Terminal Co. v. Central Union Trust Co, 271 U.S. 445,455 (1926). Thus, the court made clear that maintenance of the old securities stratification was not required by absolute priority. 
While $D u$ Bois was pending in the Supreme Court, the Tenth Circtit's approval of another reorganization in Standard Gas \& Electric Co. v. Decp Rock Oil Corp. ${ }^{114}$ demonstrated the Supreme Court's doctrines in application. Senior noteholders held claims of $\$ 14.35$ million, while their compensation was valued at $\$ 14.91$ million. Of this amount, $\$ 2.9$ million was distributed in cash and the remainder in new notes and common stock. ${ }^{115}$ In answer to the objections of junior claimants, the court held that the excess value of the distribution was necessary to full compensation. Since junior interests were participating, the noteholders must receive compensation for priorities lost by partial payment in common stock. Thus the noteholders received a $4 \%$ bonus which gave them an increased share in assets and voting control. In addition, they received $20 \%$ of their claim in cash, qualitatively superior to the notes surrendered. ${ }^{110}$

Use of face amount bonuses as compensation for loss of senior rights was applied to both debentures and preferred stock in the Central States reorganization.117 Debentures and two classes of preferred were replaced with new common. Debenture holders were to receive the face amount of their claim plus $5 \% .{ }^{118}$ Senior preferred received their liquidation claim plus $2 \frac{1}{2} \% .^{110}$ Junior preferred received the remainder, and old common was wiped out. ${ }^{120}$ Since both senior classes were losing priorities, the Fourth Circuit held the

114. 117 F.2d 615 (10th Cir.), cert. denied, 313 U.S. 564 (1941). The Circuit court opinion was handed down January 13,1941. Certiorari was granted in Du Bois October 28, 1940, 311 U.S. 636, and the case decided March 3, 1941, 312 U.S. 510.

115. Standard Gas \& Electric Co. v. Deep Rock Oil Corp., 117 F.2d 615, 616-7 (10th Cir. 1941). Approximately $\$ 12$ million of the noteholders' claim was paid in new notes and common stock. Ibid.

116. Since common was the voting stock, an increase in the amount of shares received increased voting power proportionately. The Tenth Circuit, however, rested its opinion entirely on asset value of the bonus, and did not mention either voting power or the qualitative superiority of cash over the old notes. The ignoring of qualitative superiority may have been due to the fact that if payments prior to approval of the plan were eliminated, cash payments amounted to only $4.2 \%$ of the remaining claim. Id. at 617 .

117. Central States Electric Corp. v. Austrian, 183 F.2d 879 (4th Cir. 1950), cert. denied, 340 U.S. 917 (1951). The case is criticized in Billyou, Priority Rights of Priferred and Common Shares in. Bankruptcy Rcorganization, 65 HARv. L. REv. 93 (1051).

118. Central States Electric Corp. v. Austrian, supra note 117, at 882. The SEC, district court, and Fourth Circuit all agreed that for an investment company the appropriate method of valuation was the market value of securities in the portfolio rather than capitalization of anticipated earnings. Id. at 884 . For a discussion of this case in terms of claims measurement, see Comment, 61 YALE L.J. 656, 661-2, 667 (1952).

119. Central States Electric Corp. v. Austrian, supra note 117, at 881 . Since the total value of assets was $\$ 38$ million, and Debenture and senior preferred's claims totalled roughly $\$ 36.5$ million, ibid., little was left for junior preferred.

120. Allowing preferred their principal plus arrearages, the court thought it clear that "the common stockholders are many millions of dollars under water." Id. at $\$ 82$. Cf. Petition of Portland Electric Power Co., 162 F.2d 618 (9th Cir.), ccrt. denicd sub nom. Watson v. Portland Electric Power Co., 332 U.S. 837 (1947) ; In re Decp Rock Oil Corp., 113 F.2d 266 (10th Cir.), cert denied sub nom. Standard Gas \& Electric Co. v. Taylor, 311 U.S. 699 (1940). 
bonuses necessary to full compensation by arguing that, for these claimants, the proceeding was tantamount to liquidation. If compensation for loss of senior rights was not given, absolute priority would be undermined.121

The Child's Company reorganization 122 illustrates another approach. The plan provided substitution of new no-par common, representing a \$10.3 million equity, for old preferred and common. ${ }^{123}$ Rejecting preferred's contention that its $7 \%$ dividend requirement and reserve fund to guarantee dividends entitled it to additional compensation, the SEC held that only preferred's liquidation claim need be covered. On this basis, preferred was allotted $75 \%$ of the new common. ${ }^{124}$

Despite the fact that the new securities were inferior to those surrendered, the SEC found preferred fully compensated. First, they obtained roting control of the company. Second, in "normal" years, dividends would equal 7\% of their old investment plus arrearages; and in good years, they would receive $75 \%$ of the increment. ${ }^{125}$ Third, they obtained a $3 / 4$ interest in a pending $\$ 1.8$ million law suit. ${ }^{226}$ None of these benefits, said the SEC, would have accrued to them in their prior status. ${ }^{127}$ The district court agreed. ${ }^{123}$

The cases indicate no doctrinal distinctions between Chapter $\mathrm{X}$ and Section 77 reorganizations. Under Los Angeles Lumber and $D u$ Bois, as in Section 77 , full compensation requires the face amount of new securities to equal the value of those surrendered, and that something extra be given where senior rights are lost. The Chapter $\mathrm{X}$ cases, however, place more reliance on bonuses as quantitative "extras," than on the qualitative superiority of some part of the compensation. Nevertheless, both types have been employed, and in Chila"s Company, preferred's lost seniority was found compensated by improved earnings prospects, voting control, and a $3 / 4$ interest in a lawsuit.120 Finally,

121. Central States Electric Corp. v. Austrian, 183 F.2d 879, \$87-9 (4th Cir. 1950), cert. denied, 340 U.S. 917 (1951).

122. Child's Company, 27 S.E.C. 85, approa'sd, In re Child's Co., 69 F. Supp. 856 (S.D.N.Y. 1946).

123. Id. at 857 . The SEC valued corporate assets at $\$ 10,300,000$, Child's Company, 24 S.E.C. 85,130 , (1946), while the district court found them to be worth $\$ 9,980,000$. Ist re Child's Co., 69 F. Supp. 856,858 (1946).

124. Child's Company, 24 S.E.C. S5, 123-9 (1946). The SEC took the position that bankruptcy was a substitute for equity receiverships, which themselves wcre a substitute for liquidation. Liquidation preferences must, therefore, control. Ibid.

125. Id. at 131 .

126. Id. at 92. The SEC apparently accepted the trustee's view that the suit would be won.

127. Id. at 131-2.

128. In re Child's Co., 69 F. Supp. 856, 859 (1946). The plan provided no ash payment, and since preferred obtained common stock whose share $(76.67 \%)$ in total assets was almost exactly the amount of their claim, ibid., it is equally clear that no bonus of the Central States variety was given.

129. This three-fourths interest amounted to a claim of $\$ 1.35$ million or approximatcly $171 / 2 \%$ of the total claim. If received as a bonus, discounted because subject to litigation, 
Missouri-Pacific jibes with Central States' insistence that preferred stock's priorities are on the same footing as those of creditors vis-di-vis common. Thus, in bankruptcy, "full compensation" requires clear recognition of any loss of senior rights.

\section{Holding Company Act Reorganizations}

Section 11 of the Public Utility Holding Company Act requires holding company systems to simplify their structures. ${ }^{130}$ To achieve this end, reorganization plans must be submitted either voluntarily by the companies or by the SEC in proceedings against them. ${ }^{131}$ Thus, reorganization under $\S 11$ arose against a background substantially different from that in bankruptcy proceedings. While insolvency was absent, over half of all holding company preferred stock had dividend arrearages. ${ }^{132}$ Although "fair and equitable" remained the criterion, full recognition of liquidation claims would have eliminated many common stockholders and increased industry-wide hostility to the Act. ${ }^{133}$

United Light and Power ${ }^{134}$ first explained full compensation in this context. The plan called for dissolution of the top holding company (Power) and transfer of its assets to its subsidiary (Railways). Power's stockholders were to become stockholders in Railways. But preferred's liquidation claims exceeded the highest valuation of the assets to be transferred. ${ }^{135}$ The SEC held "absolute priority" applicable, ${ }^{136}$ but found that in $\S 11$ it had quite a different meaning than in bankruptcy. In bankruptcy reorganizations creditors were

this interest would bring the Childs case in line with Central States. But the reasoning of the district court and SEC do not require such a conclusion, and it is possible that they felt that increased earnings and voting control, though the result of lost seniority, compensated for the loss.

130. 49 STAT. 820 (1935), 15 U.S.C. $\$ 79 \mathrm{~K}$ (1946). For an overall appraisal of the Act's background, objectives, and achievements see Comment, Section 11(b) of the Folding Company Act: Fifteen Years in Retrospect, 59 Yale L.J. 1088 (1950). See also Dodd, The Relative Rights of Preferred and Common Shareholders in Recapitalization Plans under the Holding Company Act, 57 Harv. L. Rev. 295 (1944); Note, 93 U. of PA. L. REv. 308 (1945).

Section 11(b) (2) of the Act states three grounds for requiring simplification: (1) Where voting power is unfairly distributed, (2) Where there are more than two levels of holding companies, (3) Where the operating companies controlled do not constitutc an integrated system.

131. $\S \S 11(\mathrm{e})$ and $11(\mathrm{~b})(2)$. Most companies chose the former method. Comment, supra note 130 , at 1107 .

132. Dodd, stipra note 130 , at 308.

133. See Comment, supra note 130 , at 1111 .

134. 13 S.E.C. 1 (1943). While this was not the first $\$ 11$ case, it was the one that fixed the pattern for later cases. For an earlier SEC decision under the Act, see Federal Water Service Corp., 8 S.E.C. 893 (1941).

135. The SEC found the maximum value of assets to be $\$ 81.5$ million, while preferred's liquidation claim was $\$ 98.7$ million. United Light and Power Co., 13 S.E.C. 1 , 4-5 (1943).

136. Id. at 7 . 
prevented from liquidating the debtor's property, and therefore their liquidation rights must be protected. ${ }^{137}$ Here, the company was virtually without debt and under no financial embarrassment. Therefore the fact that preferred's liquidation claims exceeded asset value did not eliminate common if it had a present investment value. ${ }^{138}$ The SEC found that if all anticipated carnings, absent reorganization, were applied to preferred arrearages they could be eliminated in about 15 years. Thenceforward, $\$ 2,585,000$ annually would be available for common dividends. ${ }^{139}$ Thus, common had a right to future income which, "on an overall judgment basis ... not susceptible of mathematical computation," entitled it to a $5 \%$ share of Railways' stock. Preferred received the remainder. ${ }^{140}$

By determining common's value first, the SEC reversed bankruptcy reorganization procedure. Findings that preferred was fully compensated by the remainder were omitted, perhaps on the theory that the whole is equal to the sum of its parts. ${ }^{\mathbf{1 4 1}}$ Nor was any attempt made to determine whether securities allocated to preferred in fact compensated it for loss of its first claim on income and liquidation rights. Instead, the fact that common surrendered $95 \%$ of any future claim to earnings it would have had before reorganization, while preferred surrendered only $5 \%$ of its old priority, made the plan fair and equitable. ${ }^{142}$

In Otis \& Co. v. SEC, ${ }^{143}$ preferred appealed this decision to the Supreme Court. The Court sustained the plar on the theory that Congress had not intended $\S 11$ to render liquidation claims mature and thus visit the effects of

137. "Decisions like those in the Los Angeles Lumber and Eoyd cases are predicated on sets of facts fundamentally distinguishable from the situstion arising here. . . Creditors and other claimants are prevented from foreclosing or otherwise comrelling an actual liquidation, but new securities are distributed among them according to their contractual and other rights determined as thougl on liquidation.

"On the other hand, Power is a company virtually without debt and under no financial embarrassment in the traditional bankruptcy or equity sense." Id. at 9.

13S. Id. at 10-11. In reaching this result the SEC overruled its earlier dictum in Federal Water Service Corporation, S S.E.C. 893, 910 (1941). Under the new rule, liquidation preferences were merely a factor in determining the overall investment value. For a full discussion of this case and its role in the development of the investment value approach, see Comment, 61 Y ALE L.J. 656, 670 (1952).

139. United Light and Power Co., 13 S.E.C. 1, 17-18 (1943). The 15-year estimate was based on the rather unrealistic and optimistic assumption that all earnings during that period would in fact be used to reduce preferred's arrearages. Ilid.

140. Id. at 1S. This represented a reduction of common's interest from the $8.8 \%$ proposed by the company. Cf. Southern Colorado Power Co., 14 S.E.C. 115 (1943), discussed pages 832-3 infra. \$11 cases by and large formed a ratio pattern between years of arrearages and common participation. See Comment, 61 YALE L.J. 656, 672 n.111 (1952).

141. E.g., since common's value was $5 \%$, preferred's must be $95 \%$ of $\$ \$ 1.5$ million.

142. United Light and Power Co., 13 S.E.C. 1, 18 (1943). While this theory may not be entirely accurate in a reorganization context, preferred did receive at least one additional benefit. It gained voting control of an $\$ \$ 1$ million company.

143. 323 U.S. 624 (1945). 
public policy on one class to the benefit of another. Furthermore, since merger or consolidation would achieve the result demanded by $\$ 11$ without raising the liquidation issue, the SEC's approval of dissolution should not alter common's rights. ${ }^{144}$

Participation by common on the basis of possible rights in the distant future reached an all-time high in Sonthern Colorado Pozver. ${ }^{145}$ Again, assets ${ }^{140}$ were insufficient to meet preferred's claims, which included $\$ 1.3$ million in dividend arrearages. ${ }^{147}$ Applying the $\$ 15,000$ annual excess of anticipated future earnings over preferred's dividend claims, the SEC concluded "that there is sufficient possibility that the Class A stock (common) might some time receive some income from the company to warrant participation by Class A stock in the reorganization." Preferred was awarded $95 \%$ of the new equity, and Class $\mathrm{A}$ common $5 \% .{ }^{148}$

This conclusion, as Commissioner Healy pointed out in his dissent, is incompatible with any previously known theory of full compensation. On a liquidation basis, preferred surrendered half its claim uncompensated and received securities of lower dignity for the other half. On the Commission's income basis, preferred arrearages would not be paid off for 95 years. Then preferred would receive 34 cents per share of new common that, absent reorganization, would have gone to old common. ${ }^{140}$ In view of preferred's losses it is difficult to see how an expectation so small and so distant satisfies full compensation. Moreover, the division of new stock seems inconsistent with United Light and Power. There, 15 years of arrearages entitled preferred to 95\% participation, while here, with 95 years of arrearages, preferred received the same percentage. ${ }^{150}$

Even Southern Colorado, however, makes it clear that there are limitations to the participation of junior interests. While allowing $5 \%$ to Class A com-

144. Otis \& Co. v. SEC, 323 U.S. $624,637-9$ (1945). Three dissenting justices argued that no amount of semantics could dodge the fact that this was a liquidation. Therefore, preferred's liquidation rights applied, and since these would absorb all available securities, $5 \%$ of preferred's claim was being turned over to common in violation of "absolute priority." Id. at 642-5.

145. 14 S.E.C. 115 (1943).

146. The company's asset accounts were admittedly unrealistic, including overstatements of value as well as high values for utterly obsolete properties. The SEC ordered these book assets of $\$ 15$ million written down by over $\$ 6$ million, and the plan was formulated to comport with the written down asset figures. Southern Colorado Power Co., 14 S.E.C. $115,134-8$ (1943).

147. Id, at 125-6.

148. Id. at 130 (emphasis added). Future earnings after fixed charges were estimated at $\$ 312,000$ while preferred dividends, absent reorganization, were $\$ 297,000$. Thus, $\$ 15,000$ per year was the amount that could be applied to the $\$ 1,300,000$ of arrearages

149. Id. at 143-6.

150. The finding that common had value appears even more strained in light of the fact that feasibility required establishment of huge sinking funds. During the decade after the plan these would absorb $\$ 120,000$ of income, and thereafter $\$ 55,000$. Id. at 132-3. Either figure vastly exceeded the difference between preferred's old requirements and net earnings. 
mon, the SEC did eliminate Class $B$. This stock could not receive any dividends until Class $A$ received $\$ 330,000$ in the dividend year. This contingency was so remote as to have no investment value. ${ }^{151}$ Similarly, the Supreme Court sustained the SEC's refusal to allow anything to stock warrants in Niagura Hudson Pou'er Corp. v. Leventritt, ${ }^{102}$ despite the fact that they had a market value. The Court reasoned that any compensation of these junior-most securities would have to come from amounts allocated to seniors and thus impinge upon the SEC's determination that the plan compensated seniors fully.1203

But where a corporation's future prospects were far brighter than in Southern Colorado, full compensation changed color. In I'irginia Public Service Co. ${ }^{154}$ estimated preferred arrearages were $\$ 3.8$ million, while anticipated earnings exceeded annual preferred dividends by $\$ 500,000.155$ Recognizing a factor it had ignored in United Light and Power, the SEC pointed out that all earnings could not feasibly be applied to arrearages; consequently it would take 10 to 15 years to eliminate them. On the basis of these figures, preferred received $91 \%$ of the equity and common $9 \% .150$ The SEC concluded that the permanent right to $91 \%$ of $\$ 1.2$ million of annual earnings fully compensated preferred for surrender of its preference claims to arrearages and $\$ 600,000$ in annual dividends. ${ }^{157}$

The dichotomy between "poor" and "rich" corporations is underscored by SEC treatment of bondholders of prosperous utilities. In Communily Gas and Power Company, ${ }^{\text {tss }}$ old debenture holders received $80 \%$ of the new com-

151. Id. at 130. The plan proposed by the company had allowed Class B 1.1\%? of the new common. This portion of the plan was, therefore, disapproved. When the company amended the plan to eliminate Class B it received final SEC approval. Scuthern Colorado Power Co., 14 S.E.C. $72 S$ (1943).

152. 340 U.S. 336 (1951), recersing 179 F.2d 615 (2d Cir. 1951), Note, 60 YaLE L.J. 371 (1951). The Supreme Court indicated that a point existed where realization of value in a going concern was too remote to be compensated. Niagara Hudson Power Corp. v. Leventritt, 340 U.S. 336, 342-3 (1951). It may be questioned whether the value of warrants in this case was any more remote than that of Class A common in Soullicri Colorado.

153. Id. at 344,347. The court added that the SEC's determination of zero as a value was entitled to as much weight as its determination of any other figure. Ilid.

154. 14 S.E.C. 406 (1943).

155. Virginia Public Service Co., 14 S.E.C. 406, 431-2 (1943).

156. Id. at 433 .

157. Id. at 431. In approving $9{ }_{, k}^{\prime}$ participation of common, the SEC upped the figure suggested by the company itself. This change was probably made possible by the Commission's order that $\$ 1,200,000$ paid by l'irginia to its parent must be returned. Id. at 418 .

Similarly, in American Utilities Service Corp., 16 S.E.C. 173 (1944), a permanent right to $85 \%$ of $\$ 245,000$ in annual earnings fully compensated preferrcd for surrcnder of dividend claims of $\$ 157,000$ annually and arrearages of $\$ 700,000$. The exchange was thought compensatory because of new common's unlimited access to profits. While this reorganization would not have passed muster in a bankruptcy proceeding, this may well be due to the difference in the method of claim valuation rather than to a different approach to full compensation. Here earning power rather than liquidation rights was the valuation criterion, and on this basis compensation was full.

158. 25 S.E.C. 92, approved, In re Community Gas \& Puver Co., 71 F. Supp. 171 
mon, while old common got $20 \% .{ }^{159}$ The test of full compensation, said the SEC, citing Du Bois and St. Paul, is "if [seniors] are allocated securities of lesser quality than those surrendered, they must be compensated through an increased share in the earnings above what they would have received had there been no reorganization."160 Here the test was met, since debenture holders received stock with anticipated earnings of $\$ 75.58$ in exchange for their $\$ 60$ interest claim and surrender of senior position. ${ }^{101}$ Again, in the Standard Gas \& Electric case, ${ }^{162}$ the Third Circuit found that surrender of a $6 \%$ interest rate in return for a projected earnings rate of $10 \%$ fully compensated debentures for loss of senior position. And in this case they also received $31 \%$ of their payment in cash. ${ }^{163}$

Where senior claims are to be paid in cash, the SEC attitude contrasts even more sharply with cases like Southern Colorado. Present investment value in such situations took on a new shade of meaning. The test, accepted by the Supreme Court in SEC v. Central-Illinois Corp., ${ }^{104}$ is whether the cash received is sufficient to allow senior claimants to purchase securities equivalent to those surrendered. ${ }^{165}$ Where the SEC measured compensation by determining the probable market value absent liquidation, it had therefore satisfied the requirements of fairness and equity. ${ }^{168}$ The only ceiling on this value is the voluntary call price of the particular security, which the market price will never exceed. ${ }^{167}$

Rejecting bond principal plus accrued interest as the $\S 11$ test, the SEC in American Power \& Light Co. ${ }^{168}$ spelled out the factors used in determining investment value. The position of the debentures to be eliminated was extremely secure. Cash on hand and debt securities held by American covered debenture principal 1.63 times; and fixed charges had been earned 1.41 times from 1934 to 1944 , while interest on the debentures was being earned 3.39 times. The safety factor was further heightened, since American's portfolio

(D. Del. 1947), aff'd, 168 F.2d 740 (3d Cir.), cert. denied sub nom. Caplan v. SEC, 334 U.S. 846 .(1948), Note, 49 CoL. L. Rev. 134 (1949).

159. In re Community Gas \& Power Co., 168 F.2d 740, 742 (1948).

160. Community Gas \& Power Co., 25 S.E.C. 92, 108 (1947). "The primary measure of debenture holders' participation is not the face amount of their claim or the market value of the securities allocated. . . " Ibid.

161. Id. at 104. “. . . [D] ebenture holders are receiving a claim to prospective earnings substantially in excess of their present interest rates to compensate for their reduced position in the system and the relinquishment of their claim to accrued conditional interest." Id. at 108.

162. In re Standard Gas \& Electric Co., 151 F.2d 326 (3d Cir. 1945), cert. deliicd sub nom. Guaranty Trust Co. v. SEC, 327 U.S. 796 (1946).

163. In're Standard Gas \& Electric Co., 151 F.2d 326, 328, 328 n.4, 333 n.12 (3d Cir. 1945).

164. 338 U.S. 96 (1949).

165. SEC v. Central-Illinois Corp., 338 U.S. 96, 144 (1949).

166. Id. at 140,144 .

167. Id. at $106,144-5$.

168. 21 S.E.C. 191, 197 (1945). 
contained many senior issues in other companies. Moreover, comparable securities had a $3 \%$ rate of return, while American debentures had a $6 \%$ return. ${ }^{169}$ A $5.45 \%$ rate would, under SEC computations, give debentures an investment value equal to their $\$ 110$ voluntary call. They were entitled to compensation in this amount since the ceiling had been reached. And one issue, not callable for two years, was entitled to a premium over this amount. ${ }^{170}$

The early $\S 11$ cases seem governed by an Euclidean conception of full compensation. No examination of the amount necessary to fully compensate preferred claimants was made. Instead, their participation was determined by subtracting the residual interest of the old common from the total to be distributed. By stretching its fact-finding powers to the limit, as in Southern Colorado, the SEC found everyone fully compensated, thus by-passing preferred's lost seniority and the remoteness of common's expectations.

Where the SEC dealt with prosperous utilities, the results were quite different. While liquidation values were uniformly discarded in favor of investment value, senior interests in wealthier utilities received more substantial awards. Where bonds and preferred received new securities, an attempt was made to balance new income claims against old. And, in the case of bonds, bonus income claims were given for surrender of senior rights. Moreover, where sufficient cash was available, senior interests received money-payment for the face amount of their claims. Thus, in some cases seniors received compensation as full as or fuller than that given in bankruptcy reorganizations. In others, "full compensation" was merely a meaningless phrase.

\section{0b of the Interstate Comarerce Act}

Enacted in $1948, \S 20 \mathrm{~b}$ of the Interstate Commerce Act was the product of dissatisfaction with $\S 77$ 's lengthy and expensive proceedings and its elimination of junior interests on the eve of the war and post-war booms.171 Section $20 \mathrm{~b}$ allows railroads to bypass $\S 77$ through a securities modification plan if approval of the ICC and 75\% of each class of security holders is obtained.

169. American Power \& Light Co., 21 S.E.C. 191, $205-09$ (1945).

170. This estimate of $\$ 110$ was based on SEC calculations of the marlict rate for the risk these bondholders bore. Id. at 211 . As finally approved, the premium amounted to $5 \%$ of the face value of the bonds. Thus, they received $\$ 115$ on their hundred dollar par on the theory that they would, vere it not for the reorganization, be called at the first opportunity. American Power \& Light Co., 21 S.E.C. 457, 45S-9 (1945).

171. 62 Stat. 163 (1948), 49 U.S.C. $\$ 20 \mathrm{~b}$ (Supp. 1952). For discussion of $\$ 20 \mathrm{~b}$ 's background, analysis of its procedures, and variant views as to its efiects, see Hand \& Cummings, Consensual Securities Modification, $63 \mathrm{HAnv}$. L. Rev. 957 (1950); Hand \& Cummings, The Railroad Modification Law, 48 CoL. L. Rev. 689 (1943); IVren, Frasibility and Fairness in Section $20 b$ Reorganizations, 52 CoL. L. Rev. 715 (1952); Comment, Streanlined Capital Readjustment Under Scction $20 \mathrm{~b}$ of the Interslate Commerce Aet, 58 YALE L.J. 1291 (1949). \$20b's valuation of claims is analyzed and compared to other reorganization valuation procedures in Comment, 61 Y ALE L.J. 656, 676-635 (1952). 
To approve, the ICC must find the plan in the "best interests" of each class, and securities allocations "just and reasonable."172 The statute significantly omits the words "fair and equitable" and makes plans binding on all security holders, when approved.

Lehigh Valley ${ }^{173}$ was the first case under $20 \mathrm{~b}$. The road, though solvent, faced a bleak financial picture. Forty-five million dollars of first lien bonds, comprising over one-third of all indebtedness, were due within eight years. In addition, there were $\$ 71.7$ million in second lien bonds (Generals) whose fixed interest had not been met in eleven of the preceding twenty years. The entire equity interest consisted of $1,200,000$ shares of $\$ 50$ par common. ${ }^{174}$ The plan provided for extension and staggering of senior bond maturities and establishment of sinking funds. Three-fourths of Generals' interest was made contingent and cumulative for three years; in return, they received four shares of common per bond. Since the total stated value of common was tun changed despite this $19 \%$ increase in the number of shares, old common surrendered one-fifth of its equity to the Generals. ${ }^{170}$

The ICC based its analysis on the proposition that the standards of full compensation under $20 \mathrm{~b}$ may vary from those applied "in a proceeding contemplating liquidation of the carrier's property."176 Although their maturitics were extended, Senior bonds were fully compensated by the resulting improvement in the road's financial condition, new sinking funds and the comparatively high interest rate on their bonds. ${ }^{177}$ Generals gave up three-fourths of their fixed claim for a contingent one, but were fully compensated by receipt of $19 \%$ of the $\$ 60$ million common equity and beneficial ICC amendments. ${ }^{178}$

Perhaps inconsistently, the ICC emphasized the plan's fairness by pointing out that all interests made some sacrifice. In the Commission's view, seniors suffered least, Generals somewhat more, and common, through sinking funds,

172. The plan must also be in the public interest and "may not be adverse to the interest of any creditor." 62 STAT. 163 (1948), 49 U.S.C. \$20b(2) (Supp. 1952).

173. Lehigh Valley R.R. Securities Modification, 271 I.C.C. 553 (1949).

174. Id. at 554-5.

175. Id. at 556-67. The plan would reduce fixed charges by $\$ 2.3$ million annually, And, had it been in effect, fixed charges would have been earned in all but four of the preceding twenty years.

176. Id. at 591 .

177. Id. at 588. The interest rate on these bonds was, with a minor exception, $4 \% / 2 \%$ or better, and over half carried $5 \%$ or $6 \%$ rates. Id. at 555 . The ease with which bondholders were found fully compensated may in part be due to the fact that they did not object to the plan.

178. Id. at 591-2. Objecting General bondholders argued that the plan violated "full priority" because the proposal itself proved that the obligation to Generals could not be met and leave an interest for stockholders. Their equity must therefore be valueless, and Generals, to be fully compensated, must receive all the common stock. Id. at 579-80. But the ICC felt that only in exceptional years would Generals be injured by the change from fixed to contingent interest. Id. at 589-90. To protect them further against occasional periods of low income, their cumulative rights were extended to five years and they were given the power to elect $1 / 3$ of the road's directors whenever four years of arrearages accrued. Id. at 593-4. 
dividend restrictions, and loss of one-fifth of their equity, yielded most. Because common was the junior security, it was entirely proper that they bear the greatest loss. ${ }^{179}$ The ICC then pronounced the plan "just and reasonable" without reconciling its finding of full compensation with its dicfa on relative sacrifice.

This ambiguity was carried over into subsequent ICC opinions. In Maryland \& Pennsylvania, ${ }^{180}$ the road relied on Lehigh l'alley in making bond interest contingent, cumulative for 5 years. In exchange, 4 shares of common were to be issued per bond. The ICC held Lehigh I alley inapplicable because the prospective earnings of the road might not cover the new contingent charges. If this were allowed, bonds would make the major sacrifice; the plan was therefore amended to make interest fully cumulative. ${ }^{181}$ Bondholders were then held fully compensated.

Again, in Southern Raila'ays, ${ }^{182}$ findings resembled those in bankruptcy proceedings but dictum did not. Due dates of matured $4 \% \%$ bonds were extended in return for payment in cash, $3 \%$ bonds, and common stoels. Old common surrendered $43 \%$ of its holdings and a substantial unsecured debt. ${ }^{183}$ Admitting the $3 \%$ bond rate was low, the ICC nevertheless found bondholders fully compensated. Earnings night at first fall short of the old $4 \%$ rate, but would later exceed it as dividends on bondholders' common increased. In atdition, bondholders obtained $43 \%$ of the common, sinking funds, and improved security for new bonds. ${ }^{184}$ While the plan could be translated into $\$ 77$ terms as payment, part in cash, part in inferior securities (3\%o bonds), plus a common stock bonus, the Commission reasoned differently. Emphasizing the fact that bondholders maintained an interest in a going concern, it felt liquidation rights were not controlling. Moreover, bondholders would fare worse in liquidation or $\$ 77$ proceedings. 1 s

Rejection of the plan proposed in Mainc Central ${ }^{180}$ proved there was a limit to $20 \mathrm{~b}$ modification of senior rights. Arrearages on $5 \%, \$ 100$ par preferred had mounted to $\$ 85$ per share. A substantial surplus was on hand

179. Id. at 592,595 .

180. Maryland \& Pennsylvania R.R. Securities Modification, 275 I.C.C. 695 (1950).

181. Id. at 713-15. The 1940-1949 earnings of the road had averaged $12 \% / 2 \% 0$ balow the new contingent charges.

182. Southern Ry. Abandonment, 271 I.C.C. 605 (1949). The reorganization arose out of the Southern's abandonment of the Atlantic \& Danville Railrosd, which it had operated for fifty years. The plan was devised to restore the latter company to ogerating status and appears to have been supported as a community project by all security holders of the Atlantic \& Danville. Id. at 634, 639-40.

183. The Company owed them a total of $\$ 365,000$ or $\$ 16.75$ per share of stoct. Old First Mortgage bonds received $\$ 400$ in cash, a $\$ 10003 \%$ bond and two shares of common per $\$ 1000$ bond surrendered. Second Mortgage bonds reccived $\$ 250$ in cash, and one share of common in addition to a new bond. Id. at 639-44.

1S4. Ibid.

155. Id. at 641-2. Because of the road's financial condition, bondholders would get little except stock in a bankruptcy proceeding.

186. Mfaine Central R.R. Securities Modification, 275 I.C.C. 261 (1950). 
due to steadily increasing revenues, but management desired to fund the arrearages and simultaneously to reduce preferred's dividend rate to $4 \%$. Common could then receive dividends without payment of preferred arrearages. ${ }^{187}$ No other changes in capital structure were contemplated. The road contended that the right to $4 \%$ on $\$ 185$ was worth at least as much as the right to $5 \%$ on $\$ 100$ plus $\$ 85$ in arrearages. ${ }^{188}$

Unconvinced, preferred stockholders rejected the plan, and the ICC, indicating doubt as to the proposal's bona fides ${ }^{180}$ supported them. In the Commission's view arrearages constituted a priority, payment of which was guaranteed before common could receive dividends. The Commission was unable to say whether "the applicant is offering the preferred stockholders the fair economical equivalent of their present contract."100 But it did find elimination of preferred's arrearages, without any sacrifice by common, to be unnecessary, and not in the best interests of preferred. ${ }^{101}$ Thus, whatever else "best interests" may require, it means that common must sacrifice if senior interests are to be tampered with.

In sharp contrast, Boston \& Maine ${ }^{102}$ indicated the lengths to which "best interests" could be stretched when the ICC thought the plan necessary. Though the road's financial position was strong, it desired to simplify its complicated capital structure and thus improve marketability of securities. The stock structure consisted of: (1) prior preferred, (2) five series of first preferred, (3) non-cumulative preferred, and (4) common. Arrearages on prior preferred came to $\$ 119$ per share, while those on first preferred ran from $\$ 86.25$ to $\$ 172.50$ per share. One class each of preferred and common werc to be substituted for the old structure, and the par value of stock interests reduced from $\$ 104.3$ to $\$ 82.4$ million. ${ }^{103}$ Prior preferred's high investment value required that it receive the entire issue of new preferred plus one share of new common for each of old prior preferred. ${ }^{104}$ The ICC approved the plan. Prior preferred received inferior securities with face amounts equaling

187. Id. at 262-8.

188. Id. at 273-4. See Comment, 61 YALE L.J. 656, 679 (1952).

189. The Commission apparently was impressed with the fact that management interests owned $46.9 \%$ of the common stock. Maine Central R.R. Securities Modification, 275 I.C.C. 261, 288 (1950).

190. Id. at 282 .

191. Id. at 282-3. An additional reason for disapproval was that the plan was totally unnecessary. Since it would not promote the financial stability of the company but would merely allow common to receive dividends at an earlier date, the plan was outside the scope of $\S 20 \mathrm{~b}$. Id. at $283-7$.

192. Boston \& Maine R.R. Securities Modification, 275 I.C.C. 397 (1950), aff'd sub mom. Sakis v. United States, 103 F. Supp. 292 (D.D.C.), appeal dismissed, 344 U.S. 801 (1952).

193. Boston \& Maine R.R. Securities Modification 275 I.C.C. 397, 401-02 (1950).

194. The road discounted the arrearage claim, which it estimated would not be paid in full for 17 years, to a present worth of $\$ 78.91$. It then figured that $\$ 140$ of new $5 \%$ preferred equalled a $\$ 100$ share of old $7 \%$. Id. at 426 n.25. For a discussion of these allocations, see Comment, 61 YALE L.J. 656, 681 (1952). 
the investment value surrendered. But because the new securities would, in good years, yield a higher return than those surrendered, prior preferred was fully compensated. Moreover, it obtained voting control of the company. ${ }^{103}$

Other allocations were more difficult. If the investment value of first preferred (next ranking issue) was fully satisfied, nothing would remain for the junior classes. ${ }^{196}$ And since, absent reorganization, the junior classes had no dividend expectations for seventy-four years, the road admitted that any allocations to them must be arbitrary. ${ }^{197}$ Still, they "could not be expected to vote themselves out of existence," 198 and they were therefore allotted small portions of new common to obtain their acceptance of the plan. The ICC in effect seconded this rejection of full compensation, but gave it a new gloss. First preferred's losses were discounted because: (1) In years of low earnings they would received some income where they would not have under the old structure; (2) they would receive income immediately instead of waiting 17 years until prior preferred's arrearages were paid; (3) junior's interests were so remote that first preferred was the de facto common and their loss of seniority illusory. 199 Then, reversing its field, the Commission admitted that if first preferred's claim was fully met, junior interests would be eliminated. Finally, the ICC found the plan, including allocations made to junior classes, "just and reasonable" because the road intended to pay all arrearages eventually.200 To find otherwise, said the Commission, would give undue weight to liquidation claims. ${ }^{201}$ Subsequently, a district court approved the plan, finding first preferred's treatment compensatory.

While prior preferred's treatment may satisfy traditional notions of full compensation, the allocations between first preferred and junior interests do not. The ICC's justifications of the plan do not hold water. The theory that avoidance of prior preferred's arrearages compensated Firsts is fallacious;

195. In the future normal years the securities issued to prior preferrcd for each old share and arrearages would return $\$ 9.41$. And the predicted range of return was from $\$ 6.68$ to $\$ 12.60$. Boston \& Maine R.R. Securities Mlodification, 275 I.C.C. $397,443-4$ (1950). Prior preferred shifted from holding $22 c^{\prime} \mathrm{C}$ of voting power to contrul of $61 \mathrm{C}_{s}^{\prime} \mathrm{C}$. Id. at 446 .

196. Id. at $428-9$.

197. Ibid.

198. $I d$. at 429.

199. Id. at 414-5. The Commission may have also felt that since junior classes were receiving only $4 \%$ of the new common between them, their participation was de minimis. As finally approved, the plan allocated new securities per old share as follows:

$\begin{array}{lll} & \text { Ncw Pfd } & \text { New } C \text {. } \\ \text { Prior Preferred: } & 1.2 \mathrm{shs} & 1.0 \text { shs } \\ \text { First Preferred: } & - & 1.66 \text { to } 0.94 \text { shs } \\ \text { Non-Cumulative Pfd: } & - & 0.07 \text { shs } \\ \text { Common: } & - & 0.05 \text { shs }\end{array}$

Id. at 402,450 . Variations on first preferred were due to the five different issues.

200. Id. at 450 .

201. Ibid.

202. Sakis v. United States, 103 F. Supp. 292, $302-3$ (D.D.C. 1952). See Comment, 61 Y ALE L.J. 656, 681 (1952). 
Firsts' claim was discounted because of these very same arrearages. ${ }^{203}$ Likewise, it is difficult to accept the argument that Firsts' lost seniority was worthless when classes junior to that seniority participate. And the ICC's explanation that the road intended to pay its arrearages is equally unconvincing in the face of the elimination of all arrearages. Furthermore, insistence that full compensation of Firsts would overemphasize liquidation claims ignores the fact that Firsts' rights were computed entirely on an investment valuc basis.204 Finally, as if to add insult to injury, Firsts' voting power was reduced. 205

In at least one case, Nezo Jersey Central, 206 the ICC bluntly abandoned full compensation as a $20 \mathrm{~b}$ requirement. There, compensation for reduction of bond interest rates would have required between $\$ 13.8$ and $\$ 16$ million in new $5 \%$ preferred. Instead, bondholders received $\$ 13.7$ million in Class A common, the remainder of their loss to be made up by income on that stock. ${ }^{207}$ Since dividends on the new common were unlikely in the foreseeable future, the ICC found bondholders not fully compensated. ${ }^{208}$ Nevertheless, the plan was approved as "just and reasonable." Bondholders benefited from termination of pending bankruptcy proceedings, continuation of traffic relations with the Reading Railroad-the largest common stockholder, and general improvement in the road's financial condition. Moreover, old common, in surrendering onehalf its equity, sacrificed more than bondholders. ${ }^{200}$

The "best interests" and "just and reasonable" requirements of $20 \mathrm{~b}$ have become highly flexible tools in the hands of the ICC. Analysis of compensation, in terms of old claims and "something extra" for loss of senior rights, is less intensive than under $\S 77.210$ While Lehigh Valley and Southern Railway might be rationalized to fit bankruptcy concepts of full compensation, ${ }^{211}$ their dicta as applied in Boston \& Maine and New Jersey Central cannot. In the

203. Whereas prior preferred's arrearages were discounted for the seventeen years necessary to pay them, first preferred's principal was discounted for this period, and its arrearages were further discounted for the 74-year period estimated for their payment. Boston \& Maine R.R. Securities Modification, 275 I.C.C. 397, 426 n.25 (1950).

204. Ibid. Interestingly, the ICC argued that high earnings would compensate prior preferred, id. at 443 , and that low earnings would compensate first prcferred. Id. at 444.

205. Before the plan, they had $37 \%$ of the voting power; afterwards, 36\%. Id. at 446 .

206. Central R.R. of New Jersey Securities Modification, 271 I.C.C. 501 (1949).

207. Id. at 521-2.

208. Id. at 523 .

209. Id. at 524 .

210. Cf. Comment, 61 YALE L.J. 656, 678 (1952).

211. Lehigh Valley is probably closest to fitting the $\S 77$ mold, since capitalization of its average income for the 22 -year period prior to reorganization would, at a $4 \%$ rate, amount to $\$ 193.5$ million. If capitalized at $4 \frac{1}{2} \%$, the result would be $\$ 175.6$ million. These amounts fall rather close to the $\$ 189.5$ million book value of pre-modification securities. See Lehigh Valley R.R. Securities Modification, 271 I.C.C. 553, 555, 575-6 (1949) for the figures on which these computations are based. 
first case implicitly, and in the second explicitly, the ICC scuttled full compensation in deference to junior interests' plan-blocking power. The upshot of these decisions is that absolute priority may be enforced so long as no junior class is eliminated. Where strict adherence to full compensation would destroy any class, the rules are changed. Shifting emphasis from payment of seniors to preservation of juniors unfurls a new test. Plans will be found "just and reasonable" if in the "best interests" of senior classes. And where, as in Boston \& Maine, junior interests suffer substantially greater losses than those senior to them, the test is satisfied.

\section{Conclusion}

From the Boyd tree, bankruptcy cases have carved consistent doctrines of full compensation. St. Paul is simply a more specific statement of Du Bois' general rule. Under both, junior classes may not participate until seniors receive something extra above the face amount of old claims for surrender of contractual priorities. In practice, seniors receive partial qualitative superiority, as in the cash payments under the St. Paul remittitur and Decp Rocls plans, or a quantitative "bonus" as in Wisconsin Central and Central States. And in both settings preferred's seniority rights receive the same protection accorded to bonds. While the Supreme Court has not spoken on the point, there seems to be small reason to challenge analogous treatment of bonds and preferred. The full compensation rule is as applicable to one seniority as another, and congruent protection of contract rights probably fits investor expectations. $^{212}$

The relative uniformity of bankruptcy cases highlights the latest MissouriPacific's switch to market values as the measure of full compensation. Legal support for this result must flow from the Rio Grande decision. But that case merely holds that the Supreme Court will not reopen proceedings until shows that the cash value of seniors' compensation exceeds their claims. To carry this case beyond its holding is to fly in the face of Boyd's dictum and St. Paul's rejection of dollar valuation. Mioreover, as the ICC has pointed out, transient market values are an unreliable index of compensatory treatment. ${ }^{213}$ Feasibility requires a more stable standard, and economic theory demands a yardstick more closely attuned to long term capital costs. Absent permanent changes in the capital market, analysis of returns earned on book capital by analogous enterprises would seem a more reliable measure of compensation than market prices, which fluctuate with temporary changes in government fiscal policy.

Interpretations of full compensation in non-bankruptcy reorganizations under $\S 11$ and $\S 20 \mathrm{~b}$ are less uniform than their bankruptcy counterparts. While

212. See Comment, 61 YALE L.I. 656, 684 (1952). The average security holder is more likely to look upon himself as an investor than as either a creditor or part owner. Ibid.

213. Missouri Pacific RR. Reorganization, ICC Finance Dlst. 9918, Feb. 17, 1954, p. 64. 
the doctrine is generally invoked, its application appears dominated by a desire to avoid elimination of common stock. Where assets are sufficient to accommodate both full compensation and the common stock, treatment of seniors has been as compensatory as in bankruptcy reorganizations, or more so."14 But where assets are meager, Southern Colorado and Boston \& Maine indicate the extent to which both $\S 20 \mathrm{~b}$ and $\S 11$ allow strained findings of full compensation to camouflage obliteration of senior contract rights.

The theory of relative sacrifice, whose seeds were sown in some $\S 11$ cases, blossomed in $\S 20 \mathrm{~b}$ proceedings. So long as junior interests bear the greatest losses, seniors may be found "fully compensated." Here, relative priority has in effect supplanted absolute priority and has, through court approval of Boston \& Maine, received limited judicial support.215 Thus, full compensation is not one rule but two. Speedy enforcement of the Holding Company Act and $\S 20 \mathrm{~b}$ 's consensual nature are partially responsible for the schizophrenic nature of full compensation. But the decisions indicate a more fundamental diagnosis. In all reorganization settings, courts and commissions often insist that bankruptcy and non-bankruptcy reorganizations should be insulated from one another. ${ }^{216}$ They argue that only the former are substitutes for liquidation and are thereby distinguished from non-bankruptcy proceedings. But this distinction which views bankruptcy reorganizations as liquidation's substitute is questionable both historically and practically. Bankruptcy may have sprung from equity receiverships, but they were designed to preserve the business and avoid the consequences of liquidation. Under the equity receivership, "foreclosure sales" bore as little resemblance to reality as did "John Doe" of Replevin fame. ${ }^{217}$ Moreover, the public interest demands the continued operation of railroads and public utilities, thus barring their liquidation. And other large companies eschew liquidation because their value as going concerns exceeds their liquidation value. ${ }^{218}$ In no meaningful sense, therefore, are bankruptcy reorganizations a substitute for liquidation. A dual standard cannot be justified by pointing to an intellectual mirage.

Relative sacrifice, flying the colors of absolute priority, may reduce senior rights. Southern Colorado and Boston \& Maine, its $\S 20 \mathrm{~b}$ counterpart, illustrate how the faintest of junior interests may be rewarded at the expense of

214. This thesis is vigorously advanced in Billyou, Priority Rights of Security Holders in Bankruptcy Reorganization: New Directions, 67 HAkv. L. Rev. 553 (1954).

215. See Sakis v. United States, 103 F. Supp. 292 (D.D.C. 1952). The New Jersey Central plan, however, has never been litigated.

216. See, e.g., Missouri Pacific R.R. Reorganization, ICC Finance Dkt. 9918, Feb. 17, 1954, pp. 89-90; Central States Electric Co. v. Austrian, 183 F.2d 879 (4th Cir. 1950); American Power \& Light Co., 21 S.E.C. 191, 198 (1945); Lehigh Valley R.R. Securitics Modification, 271 I.C.C. 553, 591 (1949).

217. Billyou, supra note 214, at 580-5; Weiner, Conflicting Functions of the Upset Price in a Corporate Reorganization, 27 Col. L. Rev. 132 (1927) ; Frank, Some Realistic Reflections on Some Aspects of Corporate Reorganization, 19 VA. L. REv. 541; 19 VA. L. REv. 698 (1933).

218. See Comment, 61 YaLE L.J. 656, 683-4 (1952). 
senior claimants. And New Jersey Central proves that when "relative sacrifice" is coupled with consensual procedures, full compensation may go by the boards. Thus, $\S 20 \mathrm{~b}$ may demonstrate that its "atavistic procedure . . . could have been lifted from a railroad director's dream"-10 and reduce contractual priorities to railway tickets "good for this day and train only." Onas Only acrossthe-board insistence on absolute priority and its "something extra" corollary will prevent junior participation from eroding the contract rights given as consideration for investment in senior securities.

219. Comment, Streamlined Capital Readjustment Under Scetion 206 of the Interstate Commerce Act, 58 YaLe L.J. 1291 (1949).

220. See Justice Roberts' dissent in Smith v. Allwright, 321 U.S. 649, 669 (1914). 